\title{
Aplikasi Kompos Gulma Siam Chromolaena odorata terhadap Sifat Kimia Tanah dan Performa Tanaman Cabai
}

\author{
Vira Kusuma Dewi1), Nugroho Susetyo Putra'2), Benito Purwanto'2), Sri Hartati1), dan Santika Sari1) \\ 1) Staf Pengajar Fakultas Pertanian Universitas Padjadjaran \\ Jl. Raya Bandung Sumedang Km 21 Jatinangor \\ 2) Staf Pengajar Fakultas Pertanian, Universitas Gadjah Mada \\ Korespondensi: vira.kusuma.dewi@unpad.ac.id
}

\begin{abstract}
Chromolaena odorata (L.) is a potential compost since it has high biomass and contains calcium, manganese, potassium and nitrogen. The aim of this research was to know the potency of siam weed Chromolaena odorata compost on soil chemical and chili plant performance. The experiment was arranged in factorial randomized block design consisted of two factors and three replications. The first factor was variety of fertilizer (no fertilizer, cow manure, siam weed compost and inorganic fertilizers) and the second one was the tanglefoot (with and without tanglefoot). Overall, the results of study showed that $C$. odorata compost could increased crop performance when compared with the other fertilizers in terms of number of fruits, fresh/dry weight of fruits, dry weight of crops, and $N$ total (leaf, stem, root and fruit), though there was no difference in fresh weight of crops among treatments. Furthermore, the effect of siam weed compost was not significantly different on soil chemical if compared with all treatments. This study is likely suggesting that C. odorata compost gives a positive effect to crops performance and soil chemicals.
\end{abstract}

Keywords: Chili, Chromolaena odorata, compost fertilizer, tanglefoot

\section{PENDAHULUAN}

Gulma siam Chromolaena odorata (L) King \& H.E. Robinson dikenal oleh masyarakat umum dengan nama kirinyuh atau gulma putihan. Menurut Prawiradiputra (2006), gulma siam ini dinyatakan sebagai gulma penting dan merupakan tumbuhan perdu berkayu tahunan yang tangguh karena batangnya keras, perakarannya kuat dan dalam. Pada dasarnya, gulma siam dapat tumbuh dengan baik pada ketinggian 200 1800 m.dpl dan di tanah yang tidak subur (Grainge \& Ahmed, 1988).

Gulma siam $C$. odorata berpotensi untuk dimanfaatkan sebagai sumber bahan organik karena produksi biomassanya tinggi dan memiliki kandungan hara yang cukup tinggi. Menurut Kastono (2005) aplikasi kompos gulma siam sebanyak 20 dan 30 ton/ha dapat meningkatkan kandungan $\mathrm{C}$ organik dan bahan organik tanah. Hastuti (2001) menyatakan bahwa pangkasan $C$. odorata mengandung 2,59\% N; 0,35\% P; dan 3,02 \% K.
Hal tersebut didukung oleh Apriliyanto dan Hastuti (2012) yang menyatakan bahwa aplikasi kompos gulma siam pada pertanaman cabai memperlihatkan nilai rerata terbaik untuk bobot kering tanaman, jumlah buah dan bobot basah buah.

Aplikasi perlakuan kompos gulma siam pada pertanaman menunjukkan kandungan $\mathrm{N}$ yang lebih tinggi jika dibandingkan dengan penggunaan pupuk NPK dan kotoran sapi. Berdasarkan beberapa penelitian, jelas terlihat bahwa C.odorata adalah salah satu sumber bahan organik yang mudah diperoleh, memiliki kandungan biomassa tinggi dan tidak memiliki nilai ekonomis yang tinggi apabila dipergunakan untuk kepentingan lain (Widarto dkk, 2007). Oleh karena itu, keberadaan gulma siam berpotensi sebagai alternatif pupuk organik yang dapat bermanfaat bagi petani atau masyarakat untuk meningkatkan produksi dari berbagai komoditas pertanian. 
Beberapa upaya telah dilakukan untuk meningkatkan produksi tanaman cabai, salah satunya dengan pengelolaan budidaya tanaman melalui pemenuhan unsur hara dengan memanfaatkan bahan-bahan organik sebagai kompos. Menurut Linus dan Margono (2009), penambahan bahan organik dapat menambah unsur hara makro dan mikro didalam tanah.

Beberapa kelebihan penambahan bahan organik pada tanah adalah memperbaiki struktur tanah, menaikkan daya serap tanah terhadap air dan kehidupan mikroorganisme di dalam tanah serta sumber zat makanan bagi tanaman. Pernyataan ini juga didukung oleh Rovihandono (2008) yang menyatakan bahwa penambahan bahan organik mampu memperbaiki sifat fisik dan kimia tanah sehingga mendukung pertumbuhan tanaman secara optimal.

Cabai merupakan salah satu tanaman hortikultura yang telah lama dibudidayakan di Indonesia. Berdasarkan data statistik pertanian, Indonesia pernah tercatat sebagai negara pengekspor cabai walaupun jumlah ekspornya seringkali berfluktuasi. Beberapa kendala yang mempengaruhi keberadaan mutu cabai merah (Capsicum annum L.) sehingga produksi setiap tahunnya sering mengalami fluktuasi adalah serangan organisme pengganggu tanaman (OPT) dan masalah pengelolaan budidaya tanaman cabai.

Kementerian Pertanian menyatakan bahwa produksi cabai secara nasional selama Januari 2017 mengalami kelebihan atau surplus sebanyak 5.000 ton (Badan Pusat Statistik, 2017). Berkaitan dengan kondisi tersebut sangat diharapkan berbagai usaha untuk mendukung peningkatkan dan menjaga kestabilan produksi cabai.

Berdasarkan beberapa kajian di atas, maka penelitian ini memfokuskan pada potensi kompos gulma siam C.odorata untuk meningkatkan sifat kimia tanah dan performa tanaman cabai.

\section{BAHAN DAN METODE}

\subsection{Waktu dan Tempat Penelitian}

Penelitian dilaksanakan bulan September 2010 sampai Februari 2011 di kebun percobaan Fakultas Pertanian UGM, Banguntapan, Bantul, Yogyakarta. Analisis tanah dan pupuk ( $\mathrm{C} / \mathrm{N}$ rasio) serta analisis $\mathrm{N}$ pada jaringan tanaman dilakukan di Balai Penelitian dan Pengkajian Teknologi Pertanian (BPTP), Yogyakarta.

\subsection{Bahan dan Alat Penelitian}

Bahan yang digunakan dalam percobaan antara lain : benih cabai Galur OP 9 perbanyakan tahun 2009 Blok B3, kompos gulma siam, stardeck, gula pasir, dan bahanbahan yang digunakan dalam analisis di laboratorium.

Alat yang digunakan selama percobaan yaitu : sekop kecil, alat tulis, termohigrometer, handcounter, kotak kayu yang berukuran $2 \times 1$ x $1 \mathrm{~m}$, timbangan analitik, plastik, kuas, dan alat-alat yang digunakan untuk analisis laboratorium.

\subsection{Rancangan Percobaan}

Rancangan yang digunakan adalah Rancangan Acak Kelompok (RAK) dengan pola faktorial yang dapat dijelaskan sebagai berikut:

- Faktor pertama adalah jenis pupuk yang terdiri dari 4 taraf yaitu :

$\mathrm{G}=$ kompos gulma siam (40 ton/ ha)

$\mathrm{S}$ = pupuk kotoran sapi (40 ton/ ha)

$\mathrm{N}=$ pupuk NPK (menggunakan Urea N $46 \% 40 \mathrm{~kg} / 1000 \mathrm{~m}^{2}$, SP 36 $20 \mathrm{~kg} / 1000 \mathrm{~m}^{2}$, dan $\mathrm{KCl} 20 \mathrm{~kg} /$ $1000 \mathrm{~m}^{2}$ )

$\mathrm{K}$ = tanpa pupuk

- Faktor kedua adalah penggunaan tangle foot yang terdiri dari dua aras yaitu :

$\mathrm{A}=$ penggunaan tangle foot pada pertanaman 


$$
\mathrm{B}=\underset{\text { tanpa tangle foot }}{\text { pertanaman }} \text { pada }
$$

Berdasarkan uraian di atas, maka terdapat 8 (delapan) kombinasi perlakuan. Masingmasing kombinasi perlakuan diulang 3 (tiga) kali, sehingga terdapat 24 unit percobaan.

\subsection{Pembuatan Kompos}

Tahap pengomposan berlangsung selama 3 minggu. Pada tahap awal dilakukan pengumpulan bahan hijauan gulma siam. Selanjutnya, daun $C$. odorata dicacah halus kemudian ditimbang, dihamparkan dan ditambahkan air hingga basah serta ditaburi stardeck sebanyak 6,25 g yang digunakan untuk $25 \mathrm{~kg}$ gulma siam (dicampur rata). Campuran gulma siam dan stardeck ditimbun dalam kotak kayu berukuran 2 x 1 x $1 \mathrm{~m}$.

Setiap seminggu sekali dilakukan pembalikkan bahan kompos dan dilakukan penambahan air secukupnya untuk menjaga kelembaban. Penambahan gula pasir dilakukan pada umur kompos setelah 3 minggu untuk memberikan nutrisi pada dekomposer yang digunakan. Pada tahap ini, indikasi bahwa proses pengomposan telah berhasil apabila bahan yang ditimbun telah berubah warna hitam dan teksturnya menyerupai remahan seperti tanah humus. Sedangkan untuk pupuk kotoran sapi dilakukan proses pematangan selama 1 bulan.

\subsection{Pengolahan lahan, penanaman dan pemeliharaan tanaman}

Pengolahan lahan dilakukan bersamaaan dengan penambahan kompos gulma siam dan pupuk kotoran sapi pada tanaman dengan perlakuan tersebut. Bibit yang sudah berumur empat minggu setelah semai, diseleksi untuk ditanam. Sebelum diambil dari medium semai, bibit dibasahi terlebih dahulu agar tanaman tetap menyatu dengan tanah sehingga tidak merusak perakaran.

Pemeliharaan tanaman meliputi penyiraman, pengajiran, pembumbunan, dan penyiangan. Pada petak-petak perlakuan yang berbeda harus diberi batasan untuk membedakan antar perlakuan. Penggunaan pupuk yang digunakan untuk masing-masing petak perlakuan telah disesuaikan dengan penghitungan yang ada.

\subsection{Analisis $\mathrm{C} / \mathrm{N}$ tanah dan kadar $\mathrm{N}$ tanaman}

Analisis laboratorium dilakukan terhadap pengukuran kadar $\mathrm{C}$ dan $\mathrm{N}$ tanah serta kadar $\mathrm{N}$ pada tanaman. Analisis tanah dilakukan terhadap contoh tanah yang diambil sebelum dan sesudah penanaman. Pengambilan contoh tanah sebelum tanam dilakukan secara komposit dari 15 titik contoh yang diambil secara zig-zag. Pengambilan contoh tanah setelah panen juga dilakukan secara komposit dari 5 (lima) titik contoh yang diambil secara zigzag. Penetapan kadar C-organik dilakukan dengan metode Walkey and Black, dan penetapan $\mathrm{N}$-total tanah dilakukan dengan metode Kjeldahl.

Analisis kadar $\mathrm{N}$ tanaman dilakukan terhadap contoh daun dan buah yang diambil pada saat panen. Analisis N dilakukan dengan metode Kjeldahl dengan destruksi basah.

\subsection{Parameter Tanaman}

Variabel pengamatan dan pengukuran dilakukan terhadap parameter pada tanah, tanaman cabai, dan kondisi lingkungan yang dapat diuraikan sebagai berikut:

1. Bobot basah tanaman

Pengukuran bobot basah tanaman dilakukan terhadap tanaman pada akhir pengamatan. Bobot basah diperoleh dengan menimbang seluruh bagian tanaman. Tanaman yang diamati bobotnya adalah sampel tanaman yang dijadikan untuk pengamatan serangga dan arthropoda. Jumlah sampel sebanyak 4 tanaman pada setiap perlakuan.

2. Bobot kering tanaman 
Bobot kering tanaman merupakan berat bobot basah tanaman setelah dilakukan pengeringan.

3. Bobot basah buah

Pengamatan bobot basah buah merupakan total dari seluruh hasil panen. Bobot basah buah diperoleh dengan menimbang seluruh bagian buah. Jumlah sampel sebanyak 5 tanaman setiap perlakuan.

4. Bobot kering buah

Merupakan hasil pengeringan menggunakan oven pada hasil panen yang diperoleh.

5. Jumlah Buah

Jumlah buah dihitung pada setiap petak perlakuan masing-masing 5 tanaman.

\subsection{Analisis data}

Data hasil pengamatan diuji dengan uji $\mathrm{F}$ untuk mengetahui adanya perbedaan respons terhadap sifat kimia tanah dan performa tanaman cabai dari setiap perlakuan yang selanjutnya, dilakukan uji stastistika lanjutan dengan menggunakan Uji Jarak Berganda Duncan pada taraf 5\%.

\section{HASIL DAN PEMBAHASAN}

\subsection{Pengaruh Langsung Kompos Gulma Siam terhadap Performa Tanaman Cabai}

Hasil analisis tanaman menunjukkan bahwa pemberian pupuk mempengaruhi performa tanaman. Pada penelitian yang telah dilakukan, beberapa parameter performa tanaman yang telah diamati adalah jumlah buah, bobot basah buah, bobot kering buah, bobot basah tanaman dan bobot kering tanaman. Pemberian kompos gulma siam memberikan pengaruh yang nyata terhadap jumlah buah, bobot basah buah, bobot kering buah, bobot basah tanaman dan bobot kering tanaman apabila dibandingkan dengan kontrol, tetapi tidak memperlihatkan pengaruh nyata apabila dibandingkan dengan penggunaan pupuk NPK dan kotoran sapi (Gambar 1 dan 2).

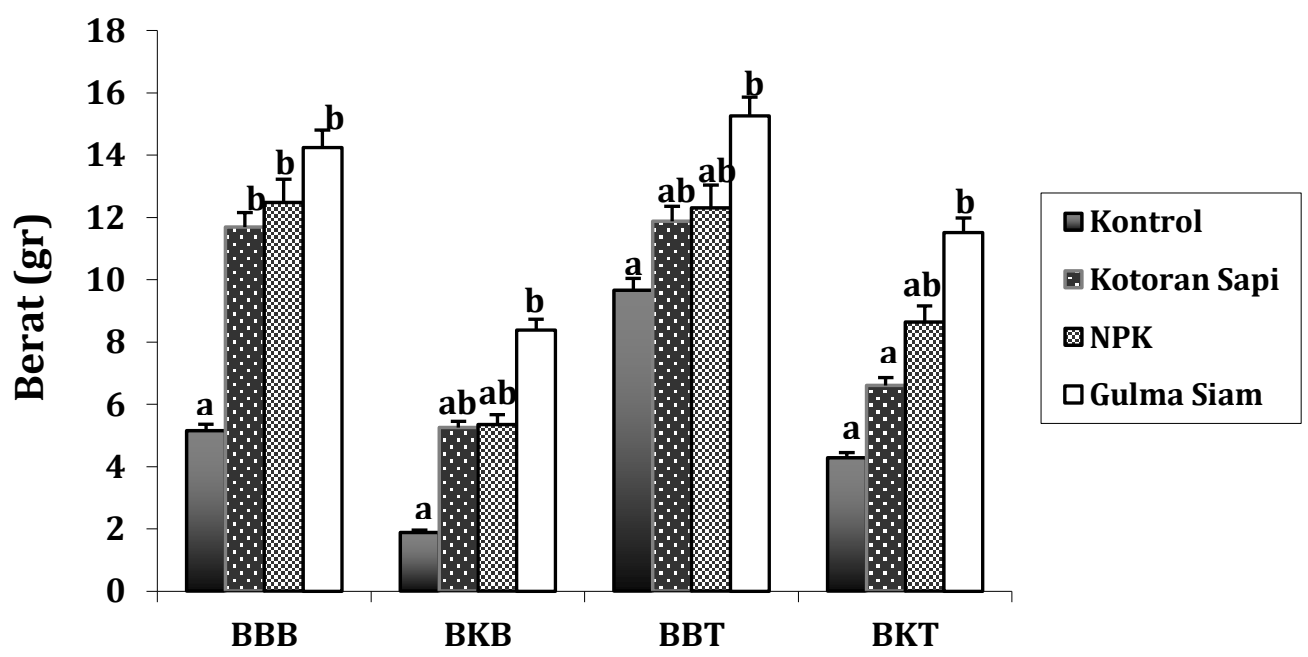

Gambar 1 Hubungan antara perlakuan jenis pupuk terhadap bobot basah buah, bobot kering buah, bobot basah tanaman dan bobot kering tanaman. BBB : Bobot Basah Buah, BKB : Bobot Kering Buah, BBT : Bobot Basah Tanaman, BKT : Bobot Kering Tanaman. 


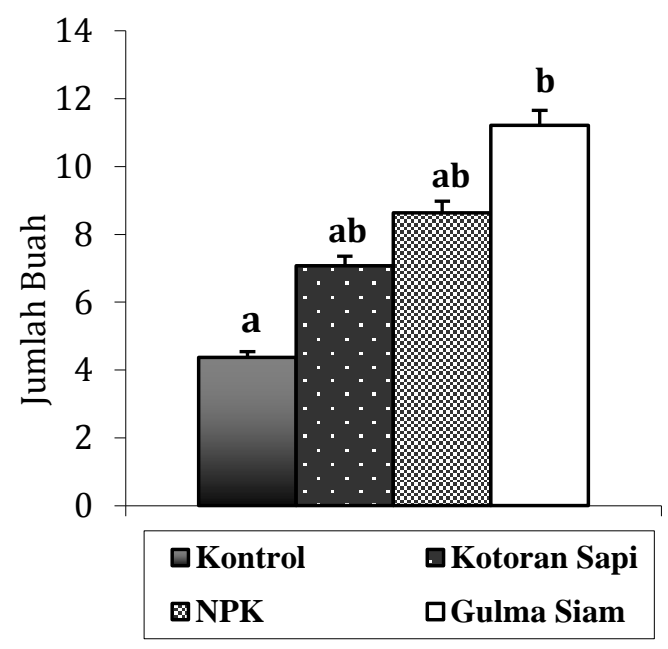

Gambar 2 Jumlah buah pada masing-masing perlakuan

Akan tetapi, pada parameter bobot kering tanaman terlihat bahwa penggunaan kompos gulma siam dan NPK memberikan pengaruh yang nyata bila dibandingkan dengan perlakuan pupuk kotoran sapi. Berdasarkan analisis tersebut maka terlihat jelas bahwa kompos gulma siam menunjukkan potensinya secara maksimal dalam peningkatan performa tanaman dibandingkan dengan penggunaan pupuk lainnya. Pernyataan tersebut didukung oleh Hakim dan Agustian (2010) bahwa kompos gulma siam berpotensi sebagai pupuk hijau, sumber bahan organik dan sumber unsur hara karena mengandung nitrogen $(\mathrm{N})$ dan kalium $(\mathrm{K})$ serta unsur lainnya seperti $\mathrm{P}$, Ca dan Mg.

Hanafiah (2007) menyatakan bahwa peranan utama nitrogen adalah merangsang pertumbuhan khususnya batang, cabang dan daun serta pengaturan fotosintesis dan pemenuhan komponen produksi. Kondisi ini berkorelasi positif dengan hasil analisis $\mathrm{C}$ dan $\mathrm{N}$ (Tabel 3) bahwa kompos gulma siam mempunyai kandungan $\mathrm{N}$ yang lebih tinggi dari pupuk kotoran sapi sebesar $1.65 \%$, sehingga diduga mampu meningkatkan performa tanaman menjadi lebih baik dibandingkan penggunaan jenis pupuk lainnya.

Tabel 2 Analisis C dan N pada kompos gulma siam dan kotoran sapi

\begin{tabular}{lcccccc}
\hline \multirow{2}{*}{ Perlakuan } & $\begin{array}{c}\text { C-organik } \\
\text { (\%) }\end{array}$ & Organik & $\mathrm{NH}_{4}$ & $\mathrm{NO}_{3}$ & Total & \multirow{2}{*}{$\begin{array}{c}\text { C/N } \\
\text { Rasio }\end{array}$} \\
\cline { 3 - 6 } Gulma Siam & 6,72 & 1,11 & 0,38 & 0,16 & 1,65 & 6 \\
KotoranSapi & 6,26 & 0,94 & 0,33 & 0,15 & 1,42 & 7 \\
\hline
\end{tabular}

Data penelitian Hastuti (2001) juga menunjukkan bahwa kompos gulma siam dapat menggantikan sumber $\mathrm{N}$ dari pupuk buatan untuk tanaman jagung mulai dari $20 \%$ sampai $100 \%$. Hal serupa juga didukung penelitian Rahayu (2008), pemberian kompos gulma siam mampu meningkatkan luas daun, berat kering tajuk, serapan $\mathrm{N}$ dan $\mathrm{C}$ pada tanaman sawi.

Menurut Hastuti (2001), peningkatan ketersediaan nitrogen pada tanaman dapat mempercepat pertumbuhan tanaman, menambah ukuran dan jumlah daun sehingga berat kering tanaman meningkat. Selain itu, pengaruh secara tidak langsung melalui perbaikan sistem perakaran yang dapat meningkatkan penyerapan unsur hara oleh akar.

Nitrogen diperlukan tanaman untuk memacu pertumbuhan tanaman. Kadar $\mathrm{N}$ total pada daun lebih tinggi dibandingkan dengan jaringan tanaman lain (Tabel 4). Berdasarkan hasil pengukuran kadar $\mathrm{N}$ pada jaringan tanaman (Tabel 4) kompos gulma siam memberikan suplai kadar $\mathrm{N}$ pada bagian daun, buah, batang dan akar lebih tinggi bila dibandingkan dengan perlakuan lainnya. Hal ini menunjukkan bahwa kompos gulma siam dapat meningkatkan performa tanaman cabai menjadi lebih baik. 
Tabel 3 Kadar N-total daun, buah cabai, batang dan akar

\begin{tabular}{|c|c|c|c|c|}
\hline \multirow[t]{2}{*}{ Perlakuan } & $\begin{array}{c}\mathrm{N} \text {-total } \\
\text { daun }\end{array}$ & $\begin{array}{c}\mathrm{N} \text {-total } \\
\text { buah }\end{array}$ & $\begin{array}{l}\mathrm{N} \text {-total } \\
\text { batang }\end{array}$ & $\begin{array}{c}\mathrm{N} \text {-total } \\
\text { akar }\end{array}$ \\
\hline & \multicolumn{4}{|c|}{ 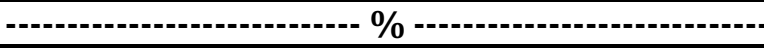 } \\
\hline Gulma Siam \& tanglefoot & 3,04 & 2,82 & 3,28 & 1,80 \\
\hline GulmaSiam \& tanpa tanglefoot & 2,79 & 2,81 & 2,94 & 2,29 \\
\hline Sapi \& tanglefoot & 3,02 & 2,57 & 2,59 & 1,61 \\
\hline Sapi \& tanpa tanglefoot & 3,13 & 2,77 & 3,54 & 1,80 \\
\hline NPK \& tanglefoot & 3,07 & 2,51 & 2,56 & 1,69 \\
\hline NPK \& tanpa tanglefoot & 2,99 & 2,51 & 2,93 & 1,69 \\
\hline Kontrol \& tanglefoot & 2,59 & 2,59 & 2,80 & 1,48 \\
\hline Kontrol \& tanpa tanglefoot & 2,72 & 2,56 & 1,79 & 1,71 \\
\hline
\end{tabular}

\subsection{Pengaruh Kompos Gulma Siam terhadap Sifat Kimia Tanah}

Hasil analisis tanah pada Tabel 3 menunjukkan bahwa sebelum perlakuan diperoleh rasio $\mathrm{C} / \mathrm{N}$ yaitu bernilai 10 . Hal ini menunjukkan bahwa kondisi lapisan olah tanah yang akan dipergunakan untuk pertanaman telah memenuhi kriteria normal rasio $\mathrm{C} / \mathrm{N}$ yaitu berkisar antara $8-12$ (Bachtiar, 2006).

Pupuk organik gulma siam dan kotoran sapi yang dipergunakan menunjukkan nilai yang rasio C/N 6 dan 7, sehingga dapat disimpulkan bahwa nilainya tidak melebih rasio $\mathrm{C} / \mathrm{N}$ tanah. Menurut Indriani (2006) bahan organik tidak dapat langsung digunakan oleh tanaman apabila perbandingan $\mathrm{C} / \mathrm{N}$ dalam bahan tersebut relatif tinggi atau tidak sama dengan $\mathrm{C} / \mathrm{N}$ tanah sehingga apabila bahan organik mempunyai kandungan $\mathrm{C} / \mathrm{N}$ mendekati atau sama dengan $\mathrm{C} / \mathrm{N}$ tanah maka bahan tersebut langsung dapat digunakan atau diserap oleh tanaman.

Hasil analisis tanah setelah perlakuan pemupukan menunjukkan bahwa rasio $\mathrm{C} / \mathrm{N}$ pada perlakuan NPK tidak berbeda nyata dengan perlakuan kompos gulma siam dan kontrol, namun berbeda nyata dengan perlakuan pupuk kotoran sapi (Gambar 3).

Tabel 3 Hasil analisis terhadap kadar C-organik, N-total, dan rasio C/N tanah sebelum dan sesudah perlakuan

\begin{tabular}{|c|c|c|c|c|c|c|}
\hline \multirow{3}{*}{ Perlakuan } & \multicolumn{3}{|c|}{ Sebelum Perlakuan } & \multicolumn{3}{|c|}{ Sesudah Perlakuan } \\
\hline & $\begin{array}{c}\text { C- } \\
\text { organik }\end{array}$ & $\begin{array}{c}\mathrm{N}- \\
\text { total }\end{array}$ & \multirow{2}{*}{$\begin{array}{c}\text { Rasio } \\
\text { C/N }\end{array}$} & $\begin{array}{c}\mathrm{C}- \\
\text { organik }\end{array}$ & $\begin{array}{c}\mathrm{N}- \\
\text { total }\end{array}$ & \multirow{2}{*}{$\begin{array}{c}\text { Rasio } \\
\text { C/N }\end{array}$} \\
\hline & \multicolumn{2}{|c|}{------ \% ------- } & & \multicolumn{2}{|c|}{ 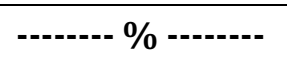 } & \\
\hline Kontrol \& tanpa tanglefoot & 1.11 & 0.11 & 10 & 1.98 & 0.21 & 9.42 \\
\hline Kontrol \& tanglefoot & 1.11 & 0.11 & 10 & 2.13 & 0.21 & 10.14 \\
\hline NPK \& tanpa tanglefoot & 1.11 & 0.11 & 10 & 2.01 & 0.21 & 9.57 \\
\hline NPK \& tanglefoot & 1.11 & 0.11 & 10 & 2.01 & 0.21 & 9.57 \\
\hline Sapi \& tanpa tanglefoot & 1.11 & 0.11 & 10 & 2.07 & 0.19 & 10.89 \\
\hline Sapi \& tanglefoot & 1.11 & 0.11 & 10 & 2.07 & 0.19 & 10.89 \\
\hline GulmaSiam\&tanpatanglefoot & 1.11 & 0.11 & 10 & 2.03 & 0.21 & 9.66 \\
\hline Gulma Siam\&tanglefoot & 1.11 & 0.11 & 10 & 2.22 & 0.21 & 10.57 \\
\hline
\end{tabular}




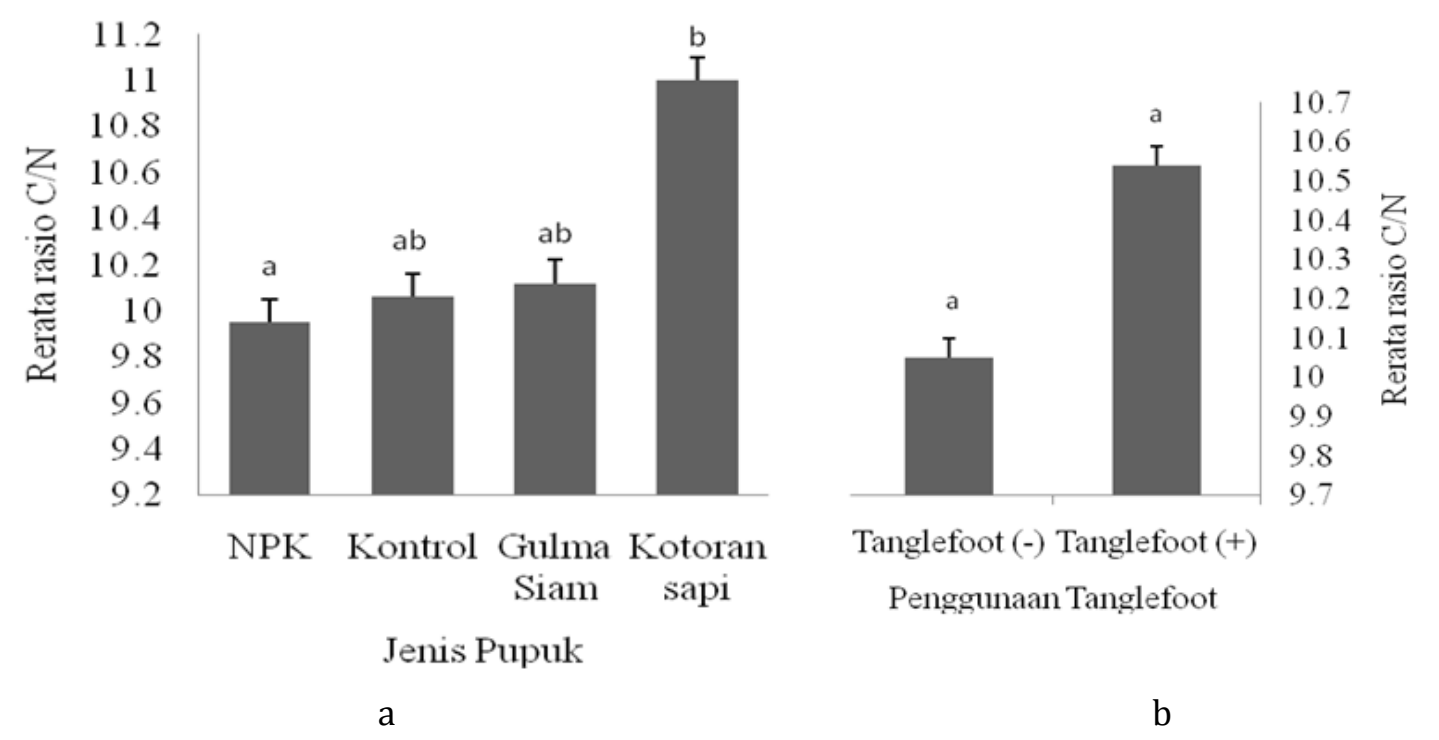

Gambar 3 Hubungan antara perlakuan jenis pupuk terhadap rerata rasio C/N(a); Hubungan antara perlakuan penggunaan tanglefoot terhadap rerata rasio $\mathrm{C} / \mathrm{N}(\mathrm{b})$.

Nilai rasio $\mathrm{C} / \mathrm{N}$ dari petak yang diberikan perlakuan pupuk kotoran sapi tidak menunjukkan perbedaan yang nyata dengan perlakuan kompos gulma siam dan kontrol. Selain itu, dijelaskan pula bahwa penggunaan tanglefoot tidak berpengaruh nyata terhadap nilai rasio C/N. Menurut Datta (1981), tanah yang memiliki rasio $\mathrm{C} / \mathrm{N}$ sebesar $10-20$ mengindikasikan bahwa kondisi tanah tergolong subur. Pernyataan ini memperkuat bahwa kondisi tanah setelah diberi perlakuan kompos gulma siam, pupuk kotoran sapi, NPK dan kontrol termasuk dalam kategori tanah yang subur karena memiliki rerata rasio $\mathrm{C} / \mathrm{N}$ sebesar 10-11.

Berdasarkan Tabel 3 rentang kadar C organik dan $\mathrm{N}$ dari beberapa jenis pupuk masing-masing adalah $1,98-2,22 \%$ dan 0,19 $0,21 \%$ maka sesuai pernyataan sebelumnya kandungan $\mathrm{C}$ dan $\mathrm{N}$ masih tergolong rendah. Penyebab dari rendahnya kandungan $\mathrm{C}$ dan $\mathrm{N}$ dikarenakan pada pertengahan fase vegetatif dan generatif mengalami masa dimana curah hujan sangat ekstrim dan terjadi penggenangan di area pertanaman yang dapat menyebabkan terjadinya berbagai reaksi kimia tanah serta runoff nutrisi. Hanafiah
(2007) juga menyatakan bahwa pengaruh bahan organik terhadap tanah dan tanaman tergantung pada laju proses dekompisisinya.

\section{KESIMPULAN}

Penggunaan kompos gulma siam mampu meningkatkan jumlah buah, bobot basah buah, bobot kering buah, bobot basah tanaman, bobot kering tanaman apabila dibandingkan dengan kontrol. Penggunaan kompos gulma siam memberikan pengaruh yang tidak berbeda nyata terhadap sifat kimia tanah apabila dibandingkan dengan semua perlakuan

\section{DAFTAR PUSTAKA}

Apriliyanto, E dan Hastuti, D. 2012. Pengaruh pemberian kompos gulma siam terhadap populasi lalat buah pada tanaman cabai. Jurnal Agroteknologi $4(1): 32-38$.

Bachtiar E. 2006. Ilmu Tanah Medan. Fakultas Pertanian USU. 
Badan Pusat Statistik. 2010. Statistik Indonesia.

De Datta, S.K. 1981. Principles and Practices of Rice Production. A Wiley-Interscience Publication. John Wiley \& Sons. New York

Grainge, M. and Ahmed, S. (1988) Handboook of Plants with Pest-Control Properties. John Wiley \& Sons, Hoboken.

Hanafiah, K.A., 2007. Dasar-dasar Ilmu Tanah. Raja Grafindo Persada, Jakarta.

Hakim, N dan Agustian. 2010. Pemanfaatan Gulma Kirinyuh sebagai Sumber Bahan Organik untuk Tanaman Sawo pada Lahan Reritis Dikecamatan Rambatan Kabupaten Tanah Datar. Laporan Penelitian.

Hastuti, P.B. 2001. Pengaruh berbagai macam bahan organik terhadap pertumbuhan dan hasil padi IR-64. Buletin Ilmiah Instiper 8:25-30.

Indriani, N.P. 2006. Pengaruh pemberian bahan organik, mikoriza, dan batuan fosfat terhadap produksi, serapan fosfor pada tanaman kudzu tropika (Pueraria Phaseoloides Benth). Jurnal Ilmu Ternak, 6(2): 158 - 162.

Kastono, D. 2005. Tanggapan pertumbuhan dan hasil kedelai hitam terhadap penggunaan pupuk organik dan biopestisida gulma siam (Chromolaena odorata). Ilmu Pertanian 12 (2) : 103-116.

Linus, P dan Marsono. 2009. Petunjuk Penggunaan Pupuk. Penebar Swadaya. Jakarta

Prawiradiputra. B.R. 2006. Kirinyuh (Chromolaena odorata (L) R.M. King dan H. Robinson): Gulma Padang Rumput yang Merugikan. WARTAZOA Vol. 17 No. 1 Th. 2007
Rahayu, D.S. 2008. Pengaruh Kompos Gulma Siam Chromolaena odorata pada Pertumbuhan Sawi dan Populasi Arthropoda. Fakultas Pertanian. Universitas Gadjah Mada. Tesis

Rovihandono, R. 2008. Memulihkan rumput sabana di sumba timur melalui pemanfaatan gulma. Spirit NTT, 4 November 2007.

Suntoro, S., E. Handayanto, \& Soemarno. 2001. Penggunaan Bahan Pangkasan Kirinyuh (Chromolaena odorata) untuk meningkatkan ketersediaan $\mathrm{P}$, $\mathrm{K}, \mathrm{Ca}$, dan Mg pada Oxid Dystrudepth di Juumapolo. Karanganyar. Jawa Tengah. Agrivita. 23(1): 20-26

Widarto, Z. Kamal \& Suroso. 2007. Penentuan kadar unsure di dalam daun krenyu dengan metode analisis neutron cepat. Dalam Prosiding Seminar Nasional III SDM Teknologi Nuklir. Hal. 377-382. Yogyakarta, 21-22 November 2007. 